\title{
Algajad õpetajad koolijuhi ja kolleegide toetusest esimestel tööaastatel
}

\author{
Marvi Remmik ${ }^{\mathrm{a}}$, Liina Lepp ${ }^{\mathrm{a}}$, Ingrid Koni ${ }^{\mathrm{a}}$ \\ a Tartu Ülikooli haridusteaduste instituut
}

\begin{abstract}
Annotatsioon
Esimestel tööaastatel peavad algajad õpetajad toime tulema erinevate olukordadega, sest sel ajal arenevad õpetamisoskused, saadakse õpetajate kogukonna liikmeks ning kujuneb õpetaja identiteet. Uurimused on näidanud, et algajad õpetajad vajavad ametisse sisseelamisel toetust, mistõttu on loodud ka mitmesuguseid tugisüsteeme. Samas on vähe tähelepanu pööratud sellele, kuidas kohanevad algajad õpetajad koolikeskkonnaga, millisena tajutakse erinevaid koolikollektiivi liikmeid enda toetajana ning mida ootavad algajad õpetajad koolikeskkonnalt kui tervikult, et õpetajatöösse paremini sisse elada. Artikli eesmärk on analüüsida algajate õpetajate kirjeldusi kohanemisest koolikeskkonnaga ja institutsiooni erinevate liikmete rolli selles. Andmete kogumiseks salvestati täies mahus ühe aasta vältel toimunud kutseaasta seminarid. Seminaridel osales 13 algajat õpetajat. Tulemused näitasid, et algajate õpetajate kogemused kooliga kohanemisel olid erinevad. Eduka kohanemise eeldusena nimetati kolleegide toetavat hoiakut ja algajate õpetajate püüdlusi igas olukorras hakkama saada. Kõige sagedasemaks koolikeskkonnaga mittekohanemise põhjuseks peeti algajate õpetajate ja institutsiooni liikmete erinevusi väärtushinnangutes. Koolijuhi osa algaja õpetaja toetajana hinnati väheoluliseks, kuna algajatel õpetajatel tööalased kokkupuuted koolijuhiga peaaegu puudusid.
\end{abstract}

Võtmesõnad: algajad õpetajad, kutseaasta, kolleegid, koolijuht, kohanemine

\section{Sissejuhatus}

Algaja õpetaja esimesed tööaastad on edasise professionaalse arengu seisukohalt otsustava tähtsusega, kuna esimesed kooli- ja õpetamiskogemused võivad olla määravad õpetajaametis jätkamisel või sellest lahkumisel (Ginns, Heirdsfield, Atweh, \& Watters, 2001). Uurimused on näidanud, et 20-50\%

1 Haridusteaduste instituut, sotsiaal- ja haridusteaduskond, Tartu Ülikool, Salme 1a, 50103 Tartu; marvi.remmik@ut.ee 
õpetajatest lahkub töölt esimese viie tööaasta jooksul (Darling-Hammond, 2003; Ingersoll \& Smith, 2003). Töölt lahkumise peamiste põhjustena on uurimustes nimetatud õpetajate suurt töökoormust (Howe, 2006; Kealy, 2010; Stokking, Leenders, De Jong, \& Van Tartwijk, 2003; Tynjälä \& Heikkinen, 2011), rahulolematust töötingimustega (Chang, 2009; Day \& Gu, 2009; Dinham \& Scott, 1996, 2000; Høigaard, Giske, \& Sundsli, 2012), ebapiisavat ettevalmistust õpetajatööks (Høigaard et al., 2012; Stokking et al., 2003) ja perekondlikke põhjusi (Darling-Hammond, 1997; Hope, 1999). Devos, Dupriez ja Paquay (2012) peavad õpetajaametiga kohanemise võtmetegureiks nii õpetaja varasemate õpingute kvaliteeti kui ka algajat õpetajat ümbritsevat sotsiaalset töökeskkonda (sh suhteid koolijuhi ja teiste kolleegidega, organisatsioonikultuuri ning mentori tuge).

Et vähendada õpetajatööd alustavate õpetajate lahkumist ametist, on mitmes riigis, sealhulgas Eestis, algaja õpetaja toetamiseks välja töötatud erinevaid tugisüsteeme. Siinses artiklis keskendutakse neist ühele - kutseaastale. Uurimustest on selgunud, et kutseaasta tegevused toetavad esimestel tööaastatel algaja õpetaja kohanemist koolikeskkonna ja õpetajatööga (vt nt Ingersoll \& Kralik, 2004; Löfström \& Eisenschmidt, 2009). Teisest küljest on teadlased kahtluse alla seadnud tugisüsteemide efektiivsuse koolides, kus puudub õpetajat toetav sotsiaalne töökeskkond ning ei olda valmis kutseaasta jooksul pakkuma algajale õpetajale igakülgset toetust (Birkeland \& Feiman-Nemser, 2012; Smith \& Ingersoll, 2004). Seetõttu on leitud, et kutseaasta tegevuste ja algajate õpetajate toetamise teema vajab edasist uurimist, ning rõhutatud vajadust mõista, millisena algajad õpetajad näevad kooli kui institutsiooni rolli nende kohanemisaastate toetajana (vt nt Bullough, 2012; Clark \& Byrnes, 2012).

Siinse uurimusega püütakse Eesti algajate õpetajate näitel teemavaldkonda avardada, analüüsides algajate õpetajate kirjelduste põhjal nende kohanemist sotsiaalse töökeskkonnaga ning kolleegide rolli selles. Eraldi tähelepanu pööratakse koolijuhtidele kui olulistele inimestele sotsiaalse töökeskkonna (sh koolikultuuri) kujundamisel.

Järgnevalt tutvustatakse uurimuse teoreetilisi lähtekohti algaja õpetaja kohanemisest sotsiaalse töökeskkonnaga (artiklis kasutatakse samas tähenduses ka mõistet koolikeskkond) ning erinevate kollektiivi liikmete rolli selles.

\section{Sotsiaalne töökeskkond algaja õpetaja toetajana}

Õpetajaks õppides ja esimestel tööaastatel peavad algajad õpetajad toime tulema erinevate olukordadega, sest saadakse õpetajate kogukonna liikmeks, arenevad õpetamisoskused ning kujuneb õpetaja identiteet (Leijen, 
Kullasepp, \& Ots, 2013; Poom-Valickis \& Löfström, 2013). Feiman-Nemser, Carver, Schwille ja Yusko (1999) nimetavad õpetaja esimest tööaastat kultuuri omandamiseks, mille käigus algajad õpetajad õpivad kolleegidelt, milline on nende kooli töökultuur ning millised on kirjutatud reeglite kõrval ka asutusesisesed tavad ja kombed. See, kuidas algajad õpetajad õpetajaametiga kohanevad, sõltub aga mitmesugustest teguritest.

Uurimused on näidanud, et õpetaja kohanemist õpetajatööga mõjutavad tema isiklik ja professionaalne taust ning õpingute ajal omandatud teadmised (Achienstein, Ogawa, \& Speiglman, 2004; Devos et al., 2012; Lawson, 1992; Tynjälä, 2013). Rainbird, Fuller ja Munro (2004) peavad kohanemisel oluliseks veel algajate õpetajate varasemaid sotsiaalseid kogemusi, kultuuritausta, suhtumist õpetajatöösse, karjääri ja õppimisse.

Peale õpetajast endast tulenevate tegurite mõjutavad algaja õpetaja kohanemist koolikeskkonnaga ka mitmed teised tegurid. Nii näiteks on uurimustest ilmnenud, et algajate õpetajate kohanemine on sujuvam ja õpetaja jaoks pingevabam, kui esimestel aastatel pakutav toetus on mitmetasandiline - õpetajat toetatakse süsteemselt ning erinevate isikute ja organisatsioonide koostöös. Näiteks osutavad Stokking ja tema kolleegid (2003), et algaja õpetaja toetus oleks tõhusam, kui koostöö õpetajakoolitusega tegeleva ülikooli ja kooli vahel oleks tihedam ja sisukam (mõlemad pooled on teadlikud üksteise ootustest ja selle nimel tegutsetakse ka tegevõpetajate koolituste kavandamisel). Samuti oleks üleminek õpetajakoolitusest õpetajatööle sujuvam, kui üliõpilased saaksid juba õpetajakoolituse ajal märksa enam viibida koolis.

Kuigi mitmed uurimused tõendavad, et koostöö eri huvigruppide (õpetajate koolitajate, koolikollektiivi, algaja õpetaja) vahel on oluline ja toimiv koostöö toetab algaja õpetaja kohanemist (vt nt Howe, 2006), leidub siiski ka uurimusi, milles on leitud, et algajate õpetajate toetamise asemel kohtab koolides jätkuvalt ka „uju või upu” suhtumist, mis õpetaja jaoks võib tähendada seda, et esimestel õpetamisaastatel tuleb iseseisvalt hakkama saada (Ingersoll \& Smith, 2003).

Lam'i ja Yan'i (2011) uurimuse tulemused näitasid, et soodne sotsiaalne töökeskkond tagas algajate õpetajate rahulolu tööga ka siis, kui õpetajad olid esialgu õpetaja töö suhtes vaid väliselt motiveeritud (nt stabiilne sissetulek). Samas juhtudel, kus algajad õpetajad olid tööle asudes sisemiselt motiveeritud, aga neil ei olnud võimalust (nt suure töökoormuse tõttu) kollektiivi liikmetega sisulist arutelu õpetamise arendamise teemadel pidada, tajusid nad koolikeskkonda ebasobivana ja sealt sooviti pigem lahkuda.

Nn sobiva ja ebasobiva koolikeskkonna kujundamisel on rõhutatud eeskätt kooli juhtkonna tegevust, mistõttu antakse järgmises osas ülevaade 
koolijuhi rollist sotsiaalse töökeskkonna kujundajana ning algaja õpetaja toetajana. Koolijuhina käsitletakse artiklis haridusasutuse (õppeasutuse) juhti (koolijuhti, direktorit, kooli juhatajat), mõistes samas, et juhtimine koolis on sageli jagatud eri isikute vahel.

\section{Koolijuht koolikeskkonna kujundajana}

Selleks, et kool oleks positiivne ja produktiivne töökeskkond õpetajatele ning toetav õpikeskkond õpilastele, näevad Davis, Darling-Hammond, LaPointe ja Meyerson (2005), Johnson (2006) ning Ladd (2011) olulisena koolijuhi rolli selle keskkonna loojana ja selles toimimise toetajana. Koolile kui institutsioonile eesmärkide ja suundade seadmine on mitmetahuline ülesanne, mistõttu peavad koolijuhid olema hariduse visionäärid, liidrid nii õppekavade kui ka õpetamise arendamisel, hindamiseksperdid, kogukonna kujundajad, suhteeksperdid, eelarve analüütikud. Lisaks oodatakse koolijuhilt pädevust nii õiguslikes, lepingulistes kui ka poliitilistes ülesannetes ja algatustes. Samuti peetakse oluliseks koolijuhi oskust lahendada konflikte nii haridusasutuse sees kui ka eri huvigruppide (nt lapsevanemate, õpetajate, õpilaste) vahel (Davis et al., 2005). Johnson (2006) toob koolijuhtide uuringute põhjal omakorda välja, et koolijuhil on täita tähtis osa igas kooliga seotud ettevõtmises, kuid eriti oluliseks peab ta, et koolijuht näitaks isiklikku eeskuju käitumisnormide väljatöötamisel ja juurutamisel.

Leithwood, Seashore Louis, Anderson ja Wahlstrom (2004) selgitavad koolijuhi ülesandeid kolme kategooria abil, milleks on 1) õpetajate arendamine, luues neile võimalused oma töö tõhusaks tegemiseks, samuti intellektuaalse toetuse pakkumine ning eeskujuks olemine praktikas; 2) õppeasutusele eesmärkide seadmine, institutsiooni toimimise ja efektiivse suhtluse edendamine; 3) vajaduse korral ümberkorralduste tegemine, loomingulise koolikultuuri tekitamine, institutsiooni struktuuri muutmine nii, et kõrvaldatakse tööd takistavad tegurid. Samuti on oluline, et koolijuht algataks ja toetaks koostööl põhinevaid protsesse.

Kuigi koolijuhil on kanda suur vastutus, ei taga see alati, et kõik kooliga seotud osapooled tajuksid juhti nende tegevusi toetavana. Varasemad uurimused edukate koolijuhtide praktikast (Blase \& Blase, 2004, viidatud Johnson, Berg, \& Donaldson, 2005 järgi) näitavad, et õpetajad tajuvad koolijuhte tõhusatena siis, kui neid on koolis näha, nad pole kitsid tunnustamisega ning annavad õpetajatele autonoomsust tegevuste kavandamisel ja elluviimisel. Nimetatud autorite tõlgenduse kohaselt parandavad need aspektid õpetajate töömotivatsiooni ja -moraali, aitavad suurendada kindlustunnet 
ning õpetajate valmidust panustada kooli arengusse. Koolijuhid, kes aga kritiseerivad, jättes väljaöeldu põhjendamata, ja kelle tegevust tajuvad õpetajad pigem kontrolliva kui toetavana, vähendavad õpetajate töömotivatsiooni.

Ülaltoodut arvestades on koolijuhil kanda sotsiaalse töökeskkonna kujundamisel vastutusrikas roll, mille suhtes on suured ootused sageli just algajatel õpetajatel, kes soovivad õpetajatöös vastata koolijuhi ootustele. Näiteks on McKerrow (1996) leidnud, et koolijuht on algajate õpetajate isoleerituse ja üksindustunde leevendamisel võtmeisikuks. Seetõttu peavad koolijuhid muu hulgas pidevalt edendama töösuhteid ning pakkuma algajale õpetajale kohanemiseks vajalikke vahendeid ja võimalusi (Clark \& Byrnes, 2012; Kouzes \& Posner, 2011). Hea ja oskuslik koolijuht peaks panustama ka sellesse, et kogenud ja algajatel õpetajatel oleks võimalik saada ühiseid töökogemusi (Johnson, 2006) - looma tingimusi kogenud ja algajate õpetajate suhtluseks ning seeläbi koos õppimiseks ja arenemiseks (Howe, 2006; Ulvik \& Langørgen, 2012). Johnson (2006) toob olulisena välja ka selle, et võimalus omavahel suhelda peaks olema tagatud eeskätt nendele õpetajatele, kes õpetavad samu õppeaineid või õpilasi. Seega aitavad algajate õpetajate rahulolutunde tekkimisele kaasa aus ja demokraatlik juhtimine, tõhus kooli haldamine ja kohane pingutuste tunnustamine koolijuhi poolt (Lam \& Yan, 2011).

Peale koolijuhi, kes toetab oma tegevuse kaudu algaja õpetaja kohanemist sotsiaalse töökeskkonnaga, on selles oluline osa ka kolleegidel. Järgnevalt peatume ühel, paljudes riikides (sealhulgas Eestis) välja pakutud algaja õpetaja toetusvõimalusel - mentorlusel.

\section{Mentorlus}

Algaja õpetaja läbipõlemise ning ametist lahkumiseni võivad viia nii toetuse, täpsemate juhiste ja juhendamise kui ka teadmiste puudumine sellest, kuidas institutsioon toimib. Uurimused on näidanud, et üks võimalus, kuidas algajat õpetajat esimesel tööaastal toetada, on mentorlus (Löfström \& Eisenschmidt, 2009; Marable \& Raimondi, 2007). Mentorluse kaudu saab toetada algaja õpetaja professionaalset õppimist ja arengut ning vähendada õpetaja isolatsiooni ja üksindustunnet (Hobson, Ashby, Malderez, \& Tomlinson, 2009).

Mentoriks määratakse enamasti samas õppeasutuses töötav kogenud õpetaja, kes nõustab ja juhendab algajat õpetajat (Clark \& Byrnes, 2012) ning pakub tuge pikaajalise mentorlussuhte jooksul (Mullen, 2005). Pidades silmas algaja õpetaja nõustamist ja juhendamist, peaks hea mentor arendama algaja õpetajaga kahesuunalist, dialoogil põhinevat koostööd (Franke 
\& Dahlgren, 1996). Paljud uurimused (vt nt Bullough, 2012; Harrison, Lawson, \& Wortley, 2005; Holloway, 2001; Löfström \& Eisenschmidt, 2009) kirjeldavad efektiivset mentorit oppimisele avatud inimesena, kes on valmis oma kogemusi jagama. Peale selle peaksid mentorid olema tunnustavad ja hoolivad, entusiastlikud ning mentori rolli suhtes positiivselt meelestatud. Beck ja Kosnik (2000) peavad muu hulgas oluliseks, et mentoriks olemine pakuks õpetajale rahulolu eeskätt seeläbi, et ta kogeb oma juhendatava edusamme ja arengut.

Hoolimata sellest, et mentorluses on nähtud head võimalust algaja õpetaja toetamisel ja koolieluga kohanemisel, on mentorlusega seotud uurimustes (vt nt Beck \& Kosnik, 2000; Smith \& Maclay, 2007; Tillman, 2003; Worthy, 2005) ilmnenud ka vastupidist - mentorlus ei ole olnud efektiivne ega andnud oodatud tulemusi. Nii näiteks leidsid oma uurimuses Beck ja Kosnik (2000), et mõned mentorid takistasid algajatel õpetajatel uuenduslike pedagoogiliste ideede rakendamist. Smithi ja Maclay (2007) uurimus näitas aga, et paljud mentorid ei olnud valmis pakkuma algajale õpetajale piisavalt emotsionaalset ja psühholoogilist toetust. Sellistel juhtudel hakkasid algajad õpetajad abi otsima mujalt, nii-öelda mitteametlikult mentorilt, kellega algaja õpetaja jagas ühiseid veendumusi ja arusaamu (Leslie, Lingard, \& Whyte, 2005).

Kokkuvõttes võib öelda, et kolleegide omavahelise suhtluse formaadist hoolimata näitavad uurimused, et kooli kui institutsiooni eesmärke saab täita siis, kui õpetajad töötavad järjekindlalt ühtse kollektiivina ning ütlevad lahti traditsioonilistest isoleerituse ja individuaalsuse normidest (Leonard \& Leonard, 2003). Seega on toetava sotsiaalse töökeskkonna loomisel oluline osa ka jagatud arusaamadel institutsioonis ja selle liikmete vahel. Järgnevalt keskendutakse jagatud arusaamade olulisusele algaja õpetaja kohanemisel koolikeskkonnaga.

\section{Jagatud arusaamad}

Birkeland ja Feiman-Nemser (2012), Nias (2005) ning Wenger (1998) rõhutavad jagatud arusaamade olulisust koolikeskkonnas tegutsemisel. Birkelandi ja Feiman-Nemseri (2012) järgi iseloomustavad toetavat koolikollektiivi ühised arusaamad 1) heast õpetamisest; 2) õpetamistöö keerulisusest ja sellest, et heaks õpetajaks kujunemine on aeganõudev protsess; 3) ühisest vastutusest kollektiivi ja õpilaste arengu eest; 4) õpetaja õppimisja arenguvõimalustest. Lisaks on Nias (2005) leidnud, et algajad õpetajad on kõige rahulolevamad sellises sotsiaalses töökeskkonnas, kus kogemuste jagamine ja koostöö on nende tegevuse loomulik osa. 
Walsdorf ja Lynn (2002) toovad õpetaja elukutse omapärana välja, et algajatel õpetajatel on tihti liiga vähe aega ja võimalusi enne kooliaasta algust teiste õpetajatega suhtlemiseks ja suhte arendamiseks ning kuna nad vastutavad täielikult õpilaste õppimise eest, täidavad õpetajad oma tööülesandeid enamasti kolleegidest eraldi. Halford (1998) peab seda ka üheks põhjuseks, miks õpetajad tunnevad oma ametis üksindust ja isoleeritust.

Seega peaks algajate õpetajate toetamisel institutsioon tervikuna ja ka individuaalsel tasandil püüdma astuda ühiselt samme selleks, et kõik õpetajad oleksid tegemistesse kaasatud ning tunneksid end kollektiivi poolt omaksvõetuna. Harrison jt (2005) on välja toonud, et „koolides, kus kogukonna tavad on nõrgad või näitavad jõudude vahekorda ja kus kaasatus on puudulik, võivad esineda suured probleemid algaja õpetaja vastuvõtmisel kollektiivi ning tema professionaalse õppimise kvaliteedis" (lk 422).

Eelnevat kokku võttes võib öelda, et algaja õpetaja kohanemisel sotsiaalse töökeskkonnaga on oluline osa koolijuhil ja mentoril kui algaja õpetaja peamistel toetajatel koolis. Samas on õpetajatööga kohanemisel tähtsad ka laiem kollektiivi toetus ning algaja ópetaja, koolijuhi ja kolleegide jagatud arusaamad. Artiklis avatakse Eesti kutseaastal osalevate algajate õpetajate näitel, mil viisil tajuvad algajad õpetajad sotsiaalse töökeskkonnaga kohanemist. Seega on artikli eesmärk analüüsida algajate õpetajate kirjeldusi kohanemisest sotsiaalse töökeskkonnaga ja institutsiooni erinevate liikmete rolli selles. Artiklis otsitakse vastuseid järgmistele küsimustele:

1) kuidas kirjeldavad algajad õpetajad sotsiaalse töökeskkonnaga kohanemist?

2) millist tuge algajate õpetajate hinnangul kolleegid neile pakuvad?

3) millised on algajate õpetajate ootused kohanemisperioodil pakutava toetuse suhtes?

\section{Kutseaasta ja kutseaasta seminarid Eestis}

Algajate õpetajate toetamiseks esimesel tööaastal rakendatakse alates 2004/2005. õppeaastast Eestis riiklikku kutseaasta programmi, mida rahastab haridus- ja teadusministeerium. Kutseaasta eest kannavad vastutust 1) koolijuhid, kelle ülesanne on aidata kaasa sotsiaalse töökeskkonna loomisele, mis toetab algajate õpetajate professionaalset arengut, ja määrata neile mentorid; 2) mentorid, kes töötavad algajate õpetajatega, toetades (mitte hinnanguid andes) nende professionaalset arengut ja sotsialiseerumist koolis; 3 ) algajad õpetajad, kes vastutavad lõppkokkuvõttes ise oma professionaalse arengu eest; 4) ülikoolide (Tartu ja Tallinna Ülikooli) kutseaasta keskused, kus 
toimuvad mentorite väljaõpe ja toetusprogrammi kutseaasta seminarid algajatele õpetajatele (Eisenschmidt, 2006).

Kutseaasta jooksul analüüsivad ja arendavad algajad õpetajad oma professionaalseid oskusi koostöös mentoriga ja nad võivad osaleda teemaseminaridel, mida korraldab ja viib läbi õpetajakoolitust pakkuv ülikool. Kutseaasta seminarid annavad algajatele õpetajatele võimaluse arutleda neile kõige olulisemate küsimuste ja probleemide üle, mis on seotud õpetaja professionaalse arenguga, efektiivselt analüüsida oma õpetamispraktikat ja õppimisel saadud kogemusi. Lisaks annab seminaridel osalemine algajatele õpetajatele võimaluse saada esimesel õpetamisaastal tuge väljastpoolt kooli. Kohtumiste graafik ja kutseaasta seminaride moodulite teemad on toodud tabelis 1 .

Tabel 1. Kutseaasta seminaride moodulite ajakava ja üldised teemad (Kutseaastat läbiva õpetaja ..., 2010)

\begin{tabular}{l|l|l}
\hline Moodul & Ajakava & Üldised teemad \\
\hline Avaseminar & $\begin{array}{l}\text { 1 päev (6 tundi), } \\
\text { septembri lõpus }\end{array}$ & $\begin{array}{l}\text { Sissejuhatus. Kutseaasta üldpõhimõtted. } \\
\text { Mured ja rõõmud koolielus }\end{array}$ \\
\hline Moodul I & $\begin{array}{l}\text { 2 päeva (kokku 12 tundi), } \\
\text { koolivaheaeg oktoobris }\end{array}$ & $\begin{array}{l}\text { Koostööoskused organisatsioonis. Mured ja } \\
\text { rõõmud koolielus }\end{array}$ \\
\hline Moodul II & $\begin{array}{l}\text { 2 päeva (kokku 12 tundi), } \\
\text { koolivaheaeg jaanuaris }\end{array}$ & $\begin{array}{l}\text { Rühmaga toimetulek ja suhted rühmas. } \\
\text { Mured ja rõõmud koolielus }\end{array}$ \\
\hline Moodul III & $\begin{array}{l}\text { 2 päeva (kokku 12 tundi), } \\
\text { koolivaheaeg märtsis }\end{array}$ & $\begin{array}{l}\text { Õpetaja õpikeskkonna kujundajana ja } \\
\text { arengu ning õppimise toetajana. Mured ja } \\
\text { rõõmud koolielus }\end{array}$ \\
\hline Lõpuseminar & $\begin{array}{l}\text { 1 päev (6 tundi), } \\
\text { mai lõpus }\end{array}$ & $\begin{array}{l}\text { Õpetaja professionaalne areng. Enese- } \\
\text { analüüsi olulisus. Läbipõlemine ja eneseabi. } \\
\text { Mured ja rõõmud koolielus. Kokkuvõte } \\
\text { kutseaastal kogetust }\end{array}$ \\
\hline
\end{tabular}

\section{Metoodika}

\section{Valimi iseloomustus}

Artikkel põhineb ühe grupi algajate õpetajate kutseaastaseminaride salvestustel õpetajakoolitusega tegelevas ülikoolis Eestis. Uuringus osales 13 algajat õpetajat, kes töötasid uuringu ajal erinevates üldhariduskoolides. Kõik seminaridel osalejad olid naissoost ja õpetamiskogemusega 1-26 kuud (keskmine õpetamiskogemus esimese seminari toimumise ajaks oli 12 kuud). Algajate õpetajate õpetatavad ained olid loodusteadused, võõrkeeled, matemaatika ja 
kodundus, klassiõpetajal põhiliselt kõik ained 1.-6. klassini. Uuringus osalenud algajate õpetajate identiteedi kaitse ja nende õppeasutuste anonüümsuse tagamise eesmärgil ei kirjeldata valimit detailsemalt.

\section{Andmekogumine}

Andmeid koguti kutseaasta seminarides ühe akadeemilise aasta jooksul (2012/2013. õppeaastal), kasutades täies mahus audiosalvestisi kutseaasta seminaris toimunud aruteludest. Kõik uuritavad osalesid uuringus vabatahtlikult ja andsid osalemiseks kirjaliku nõusoleku.

Osalejad reflekteerisid seminaris nende esimes(t)e õppeaasta(te) kogemusi, tegid teemakohaseid individuaalseid ja grupitöid. Seminaridel käsitletud teemad on esitatud tabelis 1. Igal kokkusaamisel toimus ka arutelu teemal „Mured ja rõõmud koolielus” ning samuti said osalejad tõstatada iseenda jaoks olulisi algajat õpetajat puudutavaid teemasid.

\section{Andmeanalüïs}

Kutseaasta seminaride audiosalvestised transkribeeriti täies mahus, uuritavate nimed ning seminaridel nimetatud teiste isikute nimed asendati pseudonüümidega. Andmeid analüüsiti kvalitatiivse temaatilise andmeanalüüsi meetodil, võttes aluseks Brauni ja Clarke’i (2006) esitatud andmeanalüüsi etapid. Uuringu usaldusväärsuse suurendamiseks analüüsisid kaks uurijat andmeid paralleelselt ja arutasid tulemusi erinevates andmeanalüüsi etappides. Eriarvamuste puhul arutleti seni, kuni jõuti konsensuseni (vt ka Eisner, 1991).

Alustuseks lugesid uurijad andmetega tutvumise eesmärgil seminaride transkriptsioone ja eristasid QCAmapi tarkvara abil transkriptsioonist tekstiosad, kus uuritavad rääkisid koolikeskkonnaga kohanemisest ja sellega seonduvatest ootustest ning laiemalt koostööst kolleegidega. Andmestiku teistkordsel ülelugemisel kontrolliti edasise andmeanalüüsi aluseks olevate tekstiosade kooskõla uurimuse eesmärgi ja uurimisküsimustega. Andmeanalüüsi eelfaasis tehti sügavama tekstimõistmise eesmärgil lugemise ajal märkmeid. Analüüsi esimeses etapis pandi seega andmestikuga tutvumisel kirja esialgne nimekiri teemadest (nt algaja õpetaja kohanemist soodustavad tegurid, algaja õpetaja kohanemist takistavad tegurid, suhted kolleegidega, koostöö mentoriga, koolijuhi roll esimestel tööaastatel, ootused kohanemise toetamisel). Seejärel kodeeriti analüüsi teises faasis andmed leitud esialgsete teemade raamistikus kogu andmestiku osas. Järgmiseks koondati tekkinud koodid sisu läheduse alusel alateemadeks. Näiteks moodustasid koodid „positiivne mentorlussuhe”, „neutraalne mentorlussuhe” ja „negatiivsena 
tajutav mentorlussuhe" alateema "Mentorlussuhte toimimine”. Kategoriseerimise esimese etapi järel alateemad pealkirjastati (nimetati sisule vastava üldise pealkirjaga) ja paigutati üldise teema alla. Teema nimetusi täpsustati seejuures omakorda vastavalt sisu nüanssidele. Koos alateemaga „Ootused mentorile” paigutati „Mentorlussuhte toimimine” laiema teema „Mentorlus ja kolleegide toetus" alla. Andmeanalüüsi viimase etapina kirjutati kodeerimise ja kategoriseerimise tulemusel tekkinud koondtabeli põhjal kokkuvõte alateemadest ja teemadest.

Järgnevalt esitatakse analüüsi tulemused eristunud nelja teema kaupa: oodatus kollektiivi, koolijuht algaja õpetaja toetajana, mentorlus ja kolleegide toetus ning jagatud arusaamad. Andmeanalüüsi tulemusi kinnitavad ja illustreerivad tekstilõigud transkriptsioonidest koos uuritavate pseudonüümidega.

\section{Tulemused}

\section{Oodatus kollektiivi}

Algajad õpetajad, kelle esimest tööaastat võib nende kirjelduste põhjal iseloomustada „sobiva ja toetavana”, tõid välja, et juba esimestest kontaktidest kooliga tundsid nad end kollektiivi oodatuna. Mitmel juhul olid kolleegid öelnud, et neil pole mõnda aega algajat õpetajat olnud ja nad soovivad, et algaja tunneks end hästi, ning nad on valmis pakkuma seejuures igakülgset abi ja toetust. Olulisena „oodatud õpetaja” tunde tekkimisel nimetati töövestlust, kus õppejuhataja või koolijuht andis teada, et juhtkonna poole võib igal ajal oma muredega pöörduda. Samal viisil toetas oodatuse tunnet see, kui juhtkond või kolleegid kinkisid õpetajatele kooliaasta alguses lilli ja/ või kooli logoga meeneid ning õpetajat tutvustati kolleegidele ja õpilastele õppeaasta avaüritusel.

Ta liikus minu poole ja sirutas käe ette ja .. „teie olete ilmselt uus XXX aine õpetaja". Ta oli nii avatud ja rõõmsameelne .. ja siis noh ka see, et koer tundis koera ära /.../ Noh selline täitsa super luks. (Liisa)

Ma ise esimesel päeval nagu kartsin .. ma ei teadnud kellegi nimesid /.../ Ja esimese päeva lõpus õpetajate toas, kui ma riideid selga panin, et ära minna, siis keegi küsis, et noh kuidas meie noorel kolleegil esimene tööpäev läks, ja see oli nii armas. Ma ei julgenud otsagi vaadata, aga see oli nii armas. Tõsiselt .. et et .. noh hästi toetavad ja sõbralikud. (Maris) 
Uuringus osalenute hulgas eristus kolm algajat õpetajat, kelle kohanemisaasta erines teiste grupiliikmete omast kollektiivipoolse toetuse puudumise poolest. Need õpetajad kirjeldasid oma õpetajakarjääri algust „ebasobivana” ning kooli pakutavat toetust hinnati minimaalseks. Toetust mitte tajunud algajad õpetajad leidsid, et kollektiivi mitteoodatuse tunnet süvendas asjaolu, et kolleegid ei olnud pidanud nende liitumist koolikogukonnaga oluliseks. Veelgi enam, välja toodi isegi seda, et nad tundsid kolleegide vastumeelsust liitumisel koolikollektiiviga.

Me kahekesi olime nagu sellised .. kurja juured seal. Toodi meile siia, nagu noh võetakse uut koera majja, siis vana koer on kuri, et uued kutsikad võeti, ja siis kurjad koerad istuvad seal. (Carol)

Seega pidasid algajad õpetajad kollektiivipoolse toetuse juures oluliseks, et nende liitumist kollektiiviga märgataks ja neile pöörataks sellega seoses ka tähelepanu.

\section{Koolijuht algaja õpetaja toetajana}

Algajad õpetajad kirjeldasid oma refleksioonides koolijuhti kui kaugel ja teistest kolleegidest kõrgemal seisvat visionääri, kes sekkub algaja õpetaja tegemistesse pigem vaid siis, kui tekib otsene vajadus probleemide lahendamiseks, või koolisisese asjaajamisega seonduvate küsimuste korral.

Minimaalne suhtlemine. Ma ikkagi sain aru, et mind jälgitakse ja minuga võetakse ühendust ainult sel juhul, kui ma pahandust teen. Ja kui ma olen hea laps, siis las ma olen seal .. Sest et kui on siuke käeline tegevus .. ehk siis kontrolltööd ei ole, tunnikontrolli ei ole .. hinded on korras .. uhh .. jumal tänatud, ei pea tegelema. (Liisa)

Juhtkond ikka on ... tahab olla veel kõrgemal /.../ juhtkond tahab suruda natuke kõiki ühte vormi .. kohta ja allapoole. (Carol)

Algajate õpetajate sõnul polnud enamikul neist igapäevast kokkupuudet koolijuhiga. Koolijuhist ja tema rollist kooli juhtimisel rääkisid algajad õpetajad kutseaasta seminaridel peamiselt seoses dokumentatsiooni täitmisega. Igasuguse dokumentatsiooni esitamisel oldi arvamusel, et direktor peaks kohtlema algajaid õpetajaid võrdsetel alustel kogenud kolleegidega (kui mitte paindlikumalt toimides). Ebavõrdsus nõudmistes ja kogenud kolleegidele järeleandmiste tegemine dokumentide esitamise tähtaegades tekitasid algajatele õpetajatele lisapingeid ning panid neid tundma, et nad ei ole koolijuhi silmis samaväärsed kollektiivi liikmed. 
Meil on kindel see, et meie peame tegema selleks kuupäevaks, mis on ette nähtud .. ülejäänud siis .. no neile tuletatakse meelde ja võib-olla nad ei tee siis .. Siis ma pärast kahte nädalat kuulen, et no ma ei olegi veel seda saanud nende vanade õpetajate käest, aga meile ütles samal päeval, et .. peab olema. (Carol)

Üks koolijuhi juhtimisotsustega seonduv teema, mis algajate õpetajate aruteludes üles kerkis, oli õpetajate suhtlust soodustavate kohtade olemasolu (nt õpetajate toad, ainesektsioonide kabinetid, kohvinurgad) ning sellega seoses ka algaja õpetaja klassiruumi paiknemine koolimajas. Algajad õpetajad leidsid, et kolleegidega suhtlemine on oluline ja koolijuhil on nende tingimuste loomisel kandev roll.

Kuna ma olen niimoodi õpetajate toa kõrval, siis päris tihti on nii, et õpetajad lihtsalt kui nad lähevad õpetajate tuppa, siis vahepeal astuvad minu juurest läbi .. küsivad, et kuidas sul läheb .. just esimestel nädalatel oli hästi palju seda. Ma kuidagi tunnen, et .. et alati kui mul midagi .. mingi probleem on .. ma saan .. lähen õpetajate tuppa ja alati on keegi, kes mind aitab. Et selles mõttes on hästi .. hästi super kollektiiv. (Kati)

Algajate õpetajate kirjelduste järgi vaadeldi seega koolijuhti peamiselt igapäevatööst eemal seisva visionäärina. Samas väärtustati koolijuhi panust õpetajatele suhtluskohtade loomisel ja algajale õpetajale sobivas kohas klassiruumi leidmisel.

\section{Mentorlus ja kolleegide toetus}

Kutseaasta seminaril osalenud algajad õpetajad jagunesid formaalse mentori toetuse poolest kolme rühma: 1) algajad õpetajad, kelle jaoks formaalne mentorlussuhe andis positiivse kogemuse ning kellele pakkus mentor piisavalt ja sobival ajal ning viisil vajalikku informatsiooni ja nõuandeid ning emotsionaalset toetust; 2) algajad õpetajad, kelle jaoks formaalne mentorlussuhe oli neutraalne - tuge küll ei saadud, kuid sellest ei tuntud ka puudust; 3) algajad ópetajad, kelle jaoks formaalne mentorlussuhe andis negatiivse kogemuse, mistõttu nad leidsid, et mentorlussuhe pigem takistab kui toetab neid professionaalses arengus.

Ootused mentorile ühtisid algajate õpetajate kirjeldustes samade omadustega, mida oodatakse ka toetavatelt kolleegidelt. Oluliseks peeti mentori sõbralikkust, abivalmidust, hoolivust ja toetavat kohalolekut. Väljendati ootust, et kõik kolleegid võiksid olla toetavad, aga mentorilt võib seda ka 
otseselt nõuda. Ootusi mentorile väljendati muu hulgas järgmise metafoori kaudu: „Mentor võiks olla see, kes lisab mustale roosat sekka ja roosale musta sekka" (Mari) - vajaduse korral toetab ja on samas kriitiline sõber. Mentori rollist ja ülesannetest rääkides leiti, et mentor peaks tutvustama kohe õppeaasta alguses algajale õpetajale koolielu tavasid ning konkreetse institutsiooni ja selle juhi nõudmisi, nt „Võikski siis selle koolieluga ja kooli nõudmistega ja kõigega kurssi viia" (Kati). Niisamuti peaks mentor toetama algajat õpetajat siis, kui tuge vajatakse. Oluliseks peeti mentori oskust leida suhtlemiseks ja tagasiside andmiseks sobiv aeg ja koht, nt „Ta peaks väljendama, et ta on alati olemas. Et siis kui tekib mingi probleem, et siis tule ja püüame sellele lahenduse leida, et no siuke tagala või turvalisuse tunne peab mingil määral ikka olema" (Helena). Algajad õpetajad pidasid tähtsaks ka seda, et mentor hindaks adekvaatselt algaja õpetaja vajadusi, unustamata üheskoos rõõmustada algaja õpetaja edusammude üle, nt ,et ta ei hakka kohe ka sind nagu maha tegema .. sest kui sul on niigi raske, siis .. siis ta pigem praegu hoiab ennast tagasi võib-olla" (Maris). Mentor peaks andma tagasisidet algaja õpetaja arengu kohta, lubama vaatama oma tunde (oluliseks peeti seda, et mentor ise kutsuks oma tunde vaatama) ning suunama abi otsima mitte ainult õpetamisteemalistest vestlustest, vaid ka teistelt kolleegidelt ja raamatutest, nt „et ta siis neid ideid ja mõtteid ja võibolla mingit kirjandust, kust siis leida võib-olla midagi /... / et ta siis annaks võib-olla mõne vihje, et kust siis võib leida" (Airi). Leiti ka, et mentor võiks õpetada koolis õpilasi, keda õpetab ka algaja õpetaja, kuna see võimaldab tekkida võivatele probleemidele paremini ühiselt lahendusi otsida, „sest tema tunneb seda õpilast rohkem" (Airi).

Positiivse mentorluskogemusega algajad õpetajad väärtustasid seda, et nende jaoks on olemas inimene, kes neid kuulab ja neile tagasisidet annab. Samuti peeti oluliseks, et see inimene jagaks soovitusi nii õppemeetodite kasutamise kui ka klassiga üldise toimetuleku kohta ning on vajaduse korral valmis sekkuma, kui algaja õpetaja vajab suhetes klassi või kolleegidega toetust.

Minul on hea mentor, kelle juurde võib alati minna. Kui mul oli kassis distsipliini tagamisega probleeme, siis no tema võttis asja käsile /.../ Ja siis ta vist jah natuke rääkis paari klassiga, et .. olukord on paranenud. (Helena)

Mittetoimivat mentorlussuhet iseloomustasid algajad õpetajad kolmest aspektist. Esiteks, mentoriga puudub ühisosa, nt mentor ei näita, et mõistab algaja õpetaja muresid, samuti on probleemiks erinevate ainete õpetamisest 
tingitud ühisosa puudumine või selle vähesus. Mentorit kirjeldati sellistel juhtudel kui kogenud pedagoogi, kelle jaoks algaja õpetaja mured ja ebakindlus ei olnud mõistetavad ning kes andis sellest ka algajale õpetajale märku. Teiseks, mentorlussuhe ei toimi väärtushinnangute erinevuste tõttu, nt õppimist ja õpetamist puudutavad erimeelsused õpetaja ja õpilase rolli eristamisel ning õpilastega suhtlemisel. Kolmandaks, mentorlussuhet raskendavad erinevad arusaamad mentori rollist ja ülesannetest, nt ei suhtuta algajasse õpetajasse kui võrdsesse partnerisse, mentor ei ole teadlik või ei selgita algajale õpetajale mentori ülesandeid tundide külastamisel ning ei anna kujundavat tagasisidet, ei ole toetav ega abistav.

Minu mentor on minust hästi palju vanem ja hästi suure kogemusega, aga minu arvates meil nagu puudub ühisosa või kuidagi ma ei leia seda ühist pinda, et kust edasi minna. Temaga ei anna nagu rääkida ... selles suhtes vaielda ka, et ta lihtsalt räägib seni, kuni sa ütled mhmm .. nii et ta räägibki nagu .. noh jääbki rääkima /... / Mul on nagu hästi raske olnud ka .. et ma olen tahtnud tema tundi minna, siis ta pidevalt leiab mingi põhjuse, miks ma ei saa tema tundi minna. Ühes tunnis ma käisin ja tõesti ma nägin ka, et .. no meil on nii põhimõttelised erinevused, ja kui ma üritasin pärast tundi niimoodi vaikselt rääkida, siis ta põhimõtteliselt minu arvamuse või küsimuse tegigi kohe maha ja hakkas mulle seletama ja siis ma tundsin ennast nii halvasti /.../ Mul ei ole üldse sellist tunnet, et ta oleks minu mentor. (Maris)

Ühe uuringus osalenud algaja õpetaja jaoks olid formaalse mentorluse juures probleemiks võimusuhted, sest tema mentor oli sama õppeasutuse juht. Kuna Eestis kehtiva kutseaasta korra järgi annab algaja õpetaja tegevusele kutseaastal hinnangu koolijuht, pidas algaja õpetaja enda huvides oluliseks jätta igal juhul mentorile endast mulje kui „eksimatust õpetajast”. Lisaks tekitas algajas õpetajas ebakindlust see, et ta ei saanud oma mentori tunde külastada, sest koolijuht ei õpetanud ühtegi ainet.

No mul on direktor mentor /.../ Mina kindlasti ei lähe küsima midagi oma mentori käest /.../ Tegelikult mina ei saa mitte mitte mingit abi .. aga ma .. olen selles mõttes sellega harjunud ja ma ei küsigi. Sest kui ma küsin midagi, siis see tähendab, et ma ei oska ja ma ei ole hea töötaja, kui ma ei oska. Parem ma pean tegema näo, et ma oskan kõige paremini. Et ma ei julge küsida. (Carol)

Sellistel juhtudel, kus algaja õpetaja pidas mentorlussuhet neutraalseks, täitsid mentori rolli toetavad kolleegid ja/või algaja õpetaja pereliikmed. 
Mul on ema pedagoog ja õde õpib õpetajaks /.../ Ma lähen koju ja räägin kodus ja siis ma helistan veel õele, kui mingi asi on. Ma hästi põhjalikult analüüsin ja tahan erinevaid arvamusi kuulda. (Kati)

Kokkuvõtvalt võib välja tuua, et algajate õpetajate ootused mentorile olid üldjoontes samad, mis kõigile toetavatele kolleegidele. Samas peeti mentori kui algaja õpetaja toetaja puhul oluliseks, et ta oleks vajaduse korral alati olemas ning nõu andmas. Lisaks väärtustati mentorit isikliku eeskuju andjana.

\section{Jagatud arusaamad}

Uuringu tulemused osutasid, et algajatele õpetajatele olid olulised kolleegidega jagatud arusaamad õppimisest ja õpetamisest. Samuti leiti, et koostöö ja üksteiselt õppimine pakuvad arenguvõimalust nii algajale õpetajale endale kui ka kogenud kolleegidele. Seega üks laiem teemade ring, mis algajate õpetajate refleksioonides eristus, oligi algajate õpetajate ning kollektiivi liikmete jagatud arusaamad ja väärtushinnangute sobivus või erinevused selles. Väärtushinnangute juures rõhutati peamiselt koostööd ja õpetamise kvaliteeti.

Õpetajad, kelle väärtushinnangud ühtisid kolleegide omadega, tundsid end üldiselt ka kollektiivis paremini. Oluliseks peeti seda, et arusaamad õpetamisest ja õppimisest oleksid ühesugused (nt väärtustatakse aktiivõppe meetodite kasutamist, toimuksid ühised õpetamisteemalised arutelud nii õppetöö kavandamise kui ka refleksiooni faasis) ning ka suhtlemises ja suhetes õpilastega oldaks hoolivad ja sõbralikud. Suhtluses lapsevanemate ja kolleegidega väärtustati võrdsel tasandil suhtlemist, üksteise toetamist ning kooli ja laste arengust hoolimist. Mõisteti, et kooli ja õpetajate endi professionaalseks arenguks on vajalik kõigi osaliste koostöö ning oma osa on selles õpetaja üldisel positiivsel ellusuhtumisel.

Minul on küll väga tore kollektiiv ja lapsed ja lapsevanemad ja kõik $5+$ tõesti. Kõik väärtushinnangud on klappinud. (Airi)

Vastupidi eelnevale eristusid mitmete õpetajate puhul teemad, mis puudutasid õpetamisarusaamade erinevusi ning seetõttu ka sobimatust koostöö tegemisel ja õppetöö kvaliteedi tagamisel. Algajad õpetajad, kes väärtustasid õppijate kaasamist õppeprotsessis ning olid seejuures ainealaselt nõudlikud, ei pidanud õigeks hoolimatut ja autoritaarset juhtimisstiili ja õpetamist, vähest sisulist mõttevahetust õppimise ja õpetamise üle koolijuhi ja teiste kolleegidega ning mugavuse nimel õppetöö kvaliteedis alla andmist. 
Nüüd võin öelda, oma kogemusest nägin, et väärtushinnangud maal [maapiirkonna koolis - autorite kommentaar] on absoluutselt hoopis teised, mis linnas. /.../ Distsipliini, kommete, käitumise, aine tundmise .. vabandage väga .. kõlab halvasti .. matsid jäävad matsideks. /.../ Mina ei ole nõus laskma alla oma väärtushinnanguid õpetamisele, distsipliinile, sest kui mass arvab nii, ma kas tõstan nad sinna ülesse, aga nende tasemele ma ei lange. /.../ Ma ütlen, et ei ole mõtet loopida pärleid sigade ette .. vabandage väga. (Rita)

Kui algaja õpetaja ideed ja tänapäevaste õppemeetodite kasutamine õppetöös ei leia koolis toetust ega saa konstruktiivset tagasisidet, võib algaja õpetaja professionaalne areng pidurduda. Mitmed uuringus osalenud koolikollektiiviga rahulolematud õpetajad märkisid aruteludes, et igasugused nende esitatud uudsed ideed pärsitakse juba eos ning nii võetakse neilt ära võimalus kooli arenduses kaasa rääkida ja n-ö parema kooli tekkimisse oma panus anda. Selle põhjusena nähti algajate õpetajate ja kollektiivi liikmete vahelisi erinevusi väärtushinnangutes ning mõnel juhul ka algaja õpetaja ja kollektiivi liikmete suurest vanusevahest tingitud erinevusi.

Kuigi meie arvates see on see just see, mis meile ülikoolis oli soovitatud mingi asja kohta .. nemad ütlevad EI. No sihukesed pensioniealised ikka enamus. (Carol)

Ühelt poolt olid uuringus osalenud algajad õpetajad rahulolematud, kuna nad ei saanud kolleegidelt piisavalt tähelepanu ja toetust. Samas segas mõnda uuringus osalenut ka liigne ja õpetaja hinnangul ebapedagoogiline sekkumine algaja õpetaja õpetamisse. Nendest juhtumitest rääkisid uuringus osalejad näiteks seoses kolleegi ootamatu tunnikülastusega. Ühel juhul segas ja häiris algajat õpetajat tundi vaadelnud kolleegi otsene sekkumine õpetamisse tunnivaatluse käigus. Selline käitumine süvendas algaja õpetaja hinnangul temas ebakindlust õpetamisel ning jättis temast ka õpilastele seetõttu ebapädeva mulje.

Olime vahetunnis õpetajate toas, kõik ikka rääkisime juttu ja siis kell heliseb ja õppejuhataja ütles - nii, nüüd ma tulen sinu tundi vaatama .. / .../ Noh .. minul oli pauk. Ja siis oligi peas täitsa segadus, et issand, mis ma siin tegema pidin ja mis mul mõeldud oli, ja siis proovisin ka võibolla natuke midagi rohkem teha. Tegelikult see tegi hoopis halba .. Et läks nagu võibolla liiga paljuks seda, mis ma siis tahtsin teha tunnis ja .. Et see viis mind suhteliselt endast välja. (Airi) 
Mind häiris üks asi .. keemiatund oli. Meil ei olnud teemaks võrrandite kirjutamine, aga no oli vaja üks võrrand kirjutada ja järsku siis see, kes vaatama tuli, ütles: jaa, vaadake, sinna käib veel nool ka .. ma õpikust vaatasin .. / ... / Et selles mõttes .. et .. sekkumine .. see mulle ei meeldi. (Carol)

Algajad õpetajad kirjeldasid kutseaasta seminaridel, kuidas nad nii mõnigi kord on olnud koolis dilemma ees, saades aru, et pedagoogilises suhtluses või didaktikas tehakse midagi nii, nagu pole nende hinnangul sobiv, kuid samas puudub neil algajatena julgus sekkuda. Samal põhjusel olid mitmed uuringus osalenud algajad õpetajad oma sõnul pidanud tegema ka seda, mis oli tegelikult vastuolus nende endi tõekspidamiste või arusaamadega õpetajaks olemisest. Näiteks nimetati olukordi, kus juhtkonna ja kolleegide mõjutusel oldi sunnitud parandama õpilaste hindeid ja muutma käitumishinnet nõrgema suunas põhjusel, et „meie koolis tehakse nii”.

Meil kontrollitakse .. käiakse uste taga kuulamas, et kas on vaikus /... / Ja siis ma kuulsin, kui teisest uksest tuli siis direktor ja hüppas sisse [direktor tuli kolleegi tundi - autorite kommentaar] ja siis ta mitte ei pahandanud lastega, vaid klassi ees pahandas õpetajaga .. /.../ Noh lapsed küll jäid ka ehmatusest vait, aga võibolla ei oleks pidanud see laste ees toimuma. (Carol)

Kool on selline institutsioon, kus on väga palju sellist teesklust ja välist .. või sellist asja, mida meie koolis ei tehta. Ma olen pidanud e-koolist kustutama ära oma märkusi .. parandama neid, muutma, sest kui ikkagi asi läheb politseisse, siis nõutakse, et me ei saa selliseid asju kirjutada .. (Liisa)

Tulemused osutasid, et algajate õpetajate jaoks on tähtis lähtuda õpetamisalaste otsuste tegemisel oma pedagoogilistest tõekspidamistest ja väärtushinnangutest. Samuti peeti oluliseks algaja õpetaja kohest kaasamist kooliarendusse ning tema ideede ja ettepanekute väärtustamist kolleegide poolt.

\section{Arutelu}

Varasemad uurimused on näidanud, et algajal õpetajal tuleb esimesel õppeaastal kohaneda nii koolikeskkonna kui ka talle seatud ootustega, kandes samal ajal täisvastutust õppeprotsessi eest (Vonk, 1995). Uuringus osalenud 
algajate õpetajate refleksioonide alusel võib öelda, et koolikeskkonnaga kohanemisel oli algajatele õpetajatele oluline sotsiaalne töökeskkond, eriti selles valitsevad suhted kooli juhtkonna, mentori ja teiste kolleegidega.

Varasemate uurimuste kohaselt (vt nt Ladd, 2011; Leithwood et al., 2004) peitub peamine õpetajate töötingimusi mõjutav tegur kooli juhtimise kvaliteedis ning seega avaldab koolijuht toetuse pakkuja ja innustajana suurt mõju õpetajate professionaalsele arengule. Siinse uurimuse tulemused kinnitavad osaliselt, et algajad õpetajad märkavad ja tähtsustavad koolijuhi kui koolielus olulise isiku rolli. Koolijuhi rolli algaja õpetaja toetajana nähti peamiselt töö algusfaasis ning koolijuhi tegevust kirjeldati enamasti selle kaudu, millised olid olnud isiklikud kontaktid ja kokkupuuted temaga. Muus osas kirjeldasid uuringus osalenud algajad õpetajad koolijuhti kaugelseisva visionäärina ning reflekteerides ei arutletud selle üle, milles seisneb koolijuhi roll koolikultuuri kujundamisel ning kas ja kuivõrd erinevad algaja õpetaja väärtushinnangud koolijuhi omadest. Samas ei väljendanud algajad õpetajad oma refleksioonides ka ootust, et koolijuht peaks nendega mingil viisil enam suhtlema, lahendama mentoriga seotud erimeelsusi või toetama muul viisil senisest enam nende professionaalset arengut, luues seejuures kohanemiseks sobivamaid tingimusi. Seda võib osaliselt põhjendada sellega, et algaja õpetaja ei pruugi esimesel tööaastal veel hoomata kooli kui organisatsiooni toimimise mehhanisme ning kõigi osaliste osa selles.

Ometi on varasemates uurimustes nimetatud koolijuhti võtmeisikuks, kes juhendajana toetab algaja õpetaja sisseelamist tööellu (vt nt McKerrow, 1996), ning leitud, et koolijuht peab püsivalt edendama töösuhteid ja eemaldama barjääre (vt nt Clark \& Byrnes, 2012; Kouzes \& Posner, 2011), pakkudes suhtlusvõimalusi jagatud arusaamade ja eesmärkide kujunemiseks, ning toetama koostöiseid protsesse (Leithwood et al., 2004). Ka Eestis kehtivate õigusaktide kohaselt peaks koolijuht kutseaasta käigus looma tingimused algaja õpetaja toetamiseks ja koolieluga kohanemiseks. Seega oleks algaja õpetaja võimalikult efektiivse toetamise huvides oluline, et koolijuht puutuks sagedamini ja regulaarsemalt algaja õpetajaga kokku. Tähtis on ka algaja õpetaja tööle asumise algusperioodil vastastikuse usaldussuhte ülesehitamine ja koolijuhi initsiatiiv selles ning sellekohane edasine sihipärane tegevus.

Algajate õpetajate refleksioonidest ilmnes, et algaja õpetaja kohanemisel said määravaks näiliselt väikesed detailid (nt kelle klassi kõrval asub tema klass, kellega jagatakse kabinetti). Kui koolijuhil oli onnnestunud kogemata või teadlikult viia algaja õpetaja kokku kolleegidega, kellega neil olid lähedased arusaamad õpetamisest ja õppimisest, ning tekitada seeläbi ka toetav füüsiline ja sotsiaalne keskkond, tundsid algajad õpetajad end koolis 
paremini ning nende kohanemine koolieluga oli lihtsam. Seega tuleks suurendada koolijuhtide teadlikkust suhtlusvõimaluste, -kohtade ja -tingimuste olulisusest algaja õpetaja jaoks. Ka Kouzes ja Posner (2011) ning Clark ja Byrnes (2012) on leidnud, et üheks koolijuhi otseseks ülesandeks on töösuhete kujundamine ja suhtluse võimaldamine ning takistuste kõrvaldamine. Seega on koolijuhil täita arvatust märksa tähtsam osa algaja õpetaja toetamisel. Juba töölevõtmisel tuleks koolijuhil algaja õpetajaga läbi rääkida ja kokku leppida vastastikused ootused ja võimalused. Kui kohe alguses on loodud usalduslik õhkkond ning läbi arutatud mõlema poole ootused ja vajadused ning ühtlustatud arusaamu kooli kui organisatsiooni väärtustest, on ka edasine koostöö viljakam.

Eraldi mõtteainet pakub küsimus koolijuhi enda teadlikkusest selle kohta, millist toetust algaja õpetaja võib vajada ning kuidas seda talle kõige otstarbekamalt pakkuda. Siin on kindlasti oluline koolijuhtide teadlikkus mentorluse üldpõhimõtetest tervikuna ning sellest, mille põhjal valida just konkreetsele algajale õpetajale sobiv mentor. Kuigi Eesti kutseaasta süsteemi raames koolitatakse mentoreid, siis selles valdkonnas eraldi koolijuhi koolitamisega ei tegeleta. Samas oleks see tervikliku algaja õpetaja toetussüsteemi toimimise huvides siiski üks tegevusvaldkond, millele tuleks edaspidi mõelda ja mida on vaja lähemalt uurida. Seda enam, et koolijuht peab täitma mitmesuguseid ülesandeid: pakkuma toetust õpetajatele, püstitama organisatsiooni eesmärgid ja kujundama need vajaduse korral ümber, ehitades üles koostöiseid protsesse ning väärtustades kollektiivi liikmete suhtlemist (Leithwood et al., 2004).

Uurimistulemused osutasid, et algajate õpetajate vajadus mentori ja kolleegide toetuse järele on olemas. Olulisena toodi seejuures välja jagatud arusaamade teema, mis puudutas õpilastega suhtlemist ning üldisi arusaamu õppimisest ja õpetamisest. Uuringus osalenud algajad õpetajad ootasid mentorilt sõbralikkust ja mõistvat suhtumist, aga ka kriitiliseks sõbraks olemist ning otsest sekkumist juhul, kui algaja õpetaja seda soovib. Seega pidasid algajad õpetajad oluliseks jagatud arusaamu ja väärtushinnanguid, mille põhjal nad tegid otsuseid mentorlussuhte sobivuse või mittesobivuse kohta.

Kui ühele osale uuringus osalejatest pakkus formaalne mentorlussuhe tuge, siis oli uuritavate hulgas ka neid, kes ei saanud mentorilt abi isegi siis, kui nad seda temalt küsisid, ning kelle jaoks seetõttu eksisteeris mentori toetus vaid paberil, st koolijuhi kinnitatud mentorluslepingus. Varasemad uurimused mentorluse toimimisest on näidanud, et mentori ülesanne on algajale õpetajale nõu andmine ja tema tegevuse juhtimine (Clark \& Byrnes, 2012) ning seejuures emotsionaalse toetuse (Mullen, 2005) ja dialoogipõhise koostöö pakkumine (Franke \& Dahlgren, 1996). Samuti on oluliseks peetud 
algaja õpetaja toetamist koolikogukonda sotsialiseerumisel (Marable \& Raimondi, 2007). Seega on siinse uurimuse tulemused mõtlemapanevad selles osas, et kui õigusaktide kohaselt peavad koolijuhtide poolt algajale õpetajale määratud mentorid olema läbinud mentorikoolituse ning peaksid seega olema teadlikud nii mentorluse üldpõhimõtetest kui ka mentori rollist ja ülesannetest algaja õpetaja toetamisel ning oskama oma teadmisi ka praktikas rakendada, siis ometi ei saanud kõik uuringus osalenud õpetajad seesuguse toetuse osaliseks. Algajate õpetajate aruteludest ilmnes juhtumeid, kus mentor ei olnud teadlik mentorluse peamistest põhimõtetest ning ei teinud ka algaja õpetajaga pidevat koostööd. Samuti kirjeldati juhtumeid, kus mentori ebakohase sekkumise tõttu tunti ennast õpilaste ees õpetajana ebakompetentse ja alandatuna.

Tekib küsimus, mille põhjal teeb koolijuht mentori määramisel otsuseid ning mida ja millise toetuse pakkumist ta seejuures ise väärtustab ning kuidas oma ootusi mentoriga jagab. Teiselt poolt mõjutab mentorlussuhet mentori enda motiveeritus toetada vähem kogenud kolleegi. Praegu Eestis kehtivate õigusaktide kohaselt ei ole mentorile algaja õpetaja juhendamise eest ette nähtud eraldi hüvitisi (ei rahalisi ega ajalisi). Küll aga võib koolijuht võimaluse korral need vahendid leida ja mentori tööd tasustada. Mentorina tegutsemise ainus väline hüve on see, et seda võetakse õpetaja ametijärgu tõstmisel ühe tegurina arvesse. Seetõttu oleks edaspidi vaja uurida mentorite valimise praktikat koolides. Samuti on oluline välja selgitada, mil viisil koolijuht jälgib algaja õpetaja ja mentori koostööd algaja õpetaja esimese tööaasta jooksul ning kuidas hindab protsessi, toetudes siinjuures erinevate poolte hinnangutele ja arvamustele.

Ühelt poolt eeldab toetav mentorlussuhe algaja õpetaja, mentori ja koolijuhi koostööd juba enne algaja õpetaja tööletulekut, sealhulgas arutelu selle üle, kuidas algaja õpetajaga kiiremini tuttavaks saada ning missugust toetust mentor seejuures koolijuhilt vajab ja saab. Teiselt poolt on oluline algaja õpetajaga tehtav eeltöö õpetajakoolituse jooksul: tulevasele õpetajale tuleks senisest enam tutvustada nii mentori kui ka koolijuhi rolli ja ülesandeid ning aidata algajal õpetajal mõista ennast kui tulevast õpetajat ja seeläbi jõuda ka realistlike ootuste väljaselgitamiseni. Seega peaks algaja õpetaja lõpetama õpetajakoolituse õpingud (ja praktikaperioodi) reflekteeriva praktikuna, kes mõistab oma praktikaaegse kogemuse ja teooria baasilt, millised on realistlikud ootused koolijuhile, mentorile ja kolleegidele ning kuivõrd toetavad koolikeskkonnaga kohanemist tema enda paindlikkus ja tolerantsus ning julgus ja valmisolek vajaduse korral abi küsida. Nii saaks juba esimestel ühistel aruteludel välja selgitada, millised on osaliste arusaamad mentorlusest ja võimalustest toetada algajat õpetajat konkreetses koolis. Kuna Eesti 
kutseaasta süsteemi kohaselt tegeleb mentor algaja õpetajaga vaid koolis ning laiemaid ühiseid arutelusid (nt temaatilisi ühiskoolitusi algajatele õpetajatele ja nende mentoritele) üldjuhul ei korraldata, siis võiks ühiste koolituste korraldamist kaaluda edaspidi just seetõttu, et pakkuda võimalusi arusaamade ühtlustamiseks ning seega nii algaja õpetaja kui ka mentori vajaduste ja nõudmiste mõistmiseks.

Siinse uurimuse tulemused näitavad, et algaja õpetaja jaoks on oluline suhelda peale koolijuhi ja mentori ka kolleegidega ning saada kolleegide mõistva suhtumise ja toetuse osaliseks. See on eriti vajalik juhul, kui formaalne mentorlussuhe on algaja õpetaja jaoks ebapiisav või algaja õpetaja ei jaga mentoriga samu väärtushinnanguid õpetamise ja õppimise kohta. Mittetoimiva mentorlussuhte puhul leitakse sageli endale mentor(id) kolleegide hulgast, kellega algajal õpetajal on sarnased väärtushinnangud ning jagatud arusaamad koostööst ja õpetamisest laiemalt. Seega viitavad uurimuse tulemused, et kui algajal õpetajal puudub koolijuhi ja mentori otsene tugi, kuid on olemas toetavad kolleegid, on algaja õpetaja siiski kohanemisega rahul. Selles aspektis on uurimuse tulemused kooskõlas Howe (2006) uurimuse omadega, mille kohaselt pakuvad kolleegide avatus ja sõbralikkus algajale õpetajale tuge, aidates tal kollektiivi paremini sulanduda ja toetades tema professionaalset arengut üksteiselt óppimise võimaluse kaudu. Või nagu Nias (2005) on leidnud, õpivad õpetajad palju kolleegidega suhtlemisest ja neid kuulates, mistõttu on oluline, et need inimesed ei annaks oma hinnanguid kergel käel.

Uurimuse tulemused viitavad ka sellele, et algaja õpetaja toetamisega tuleb alustada juba õpetajakoolituses ning sealt edasi õpetaja esimestes kontaktides kooliga. Enne tööle asumist peaks algaja õpetaja olema teadlik oma ootustest koolijuhile, mentorile ja kolleegidele. Sel viisil saab erinevate poolte ootusi kooskõlastada juba esimestel kokkusaamistel. Samamoodi peaks ka koolijuht ning koolis mentorina tegutsevad õpetajad ning õpetajaskond tervikuna teadvustama, millega nad saavad algajaid õpetajaid koolieluga kohanemisel toetada ning mil viisil on nad valmis ka ise algajalt õpetajalt õppima. Kuna uurimistulemused näitasid, et mitte kõik uuringus osalenud algajad õpetajad ei olnud tundnud koolijuhi, mentori ja kolleegide tuge ja mõistmist, siis tuleks edaspidi nende teemadega edasi tegeleda nii õpetajakoolituse kui ka koolijuhtide ja mentorite täienduskoolituste kaudu.

Kokkuvõtvalt võib öelda, et algaja õpetaja toetamisel on oluline koostöö ja seeläbi jagatud arusaamade kujundamine. Toimivaks koostööks on vaja üksteisega arvestada, suhtuda teemasse avatult ning jagada seisukohta, et kõigi organisatsiooni liikmete arvamused, sealhulgas algaja õpetaja omad, on arutamist väärt ja võrdväärsed. Selleks tuleks luua õpetajatele tingimused 
kolleegidega suhtlemiseks ning pakkuda neile võimalusi oma kogemuste jagamiseks. Kogemuste jagamise kaudu saab algaja õpetaja enesest teadlikumaks ning ühtlasi toetab see tema professionaalset ja kaudsemalt kogu kooli kui organisatsiooni arengut.

Ehkki uurimuse kitsaskohana võib välja tuua väikese valimi, annavad käsitletud teemad siiski mõtteainet nii koolijuhtidele, mentoritele kui ka õpetajate koolitajatele ja kutseaasta arendajatele. Uurimus pakub teavet selle kohta, millisena näevad algajad õpetajad oma kohanemist koolides ja millist toetust nad tegelikult ootavad.

\section{Tänuavaldus}

Artikli valmimist toetas Euroopa Sotsiaalfondi haridus- ja kasvatusteaduste doktorikool (1.2.0401.09-0070). Täname uuringus osalejaid sisukate arutelude eest kutseaasta seminarides ning kolleege uurimusega seotud arutelude ja käsikirja varasemale versioonile antud tagasiside eest.

\section{Kasutatud kirjandus}

Achinstein, B., Ogawa, R. T., \& Speiglman, A. (2004). Are we creating separate and unequal tracks of teachers? The effects of state policy, local conditions, and teacher characteristics on new teacher socialization. American Educational Research Journal, 41(3), 557-603. doi: http://dx.doi.org/10.3102/00028312041003557

Beck, C., \& Kosnik, C. (2000). Associate teachers in pre-service education: Clarifying and enhancing their role. Journal of Education for Teaching, 26(3), 207-224. doi: http://dx.doi.org/10.1080/713676888

Birkeland, S., \& Feiman-Nemser, S. (2012). Helping school leaders help new teachers: A tool for transforming school-based induction. The New Educator, 8(2), 109-138. doi: http://dx.doi.org/10.1080/1547688X.2012.670567

Blase, J., \& Blase, J. (2004). Handbook of instructional leadership: How successful principals promote teaching and learning (2nd ed.). Thousand Oaks: Corwin Press.

Braun, V., \& Clarke, V. (2006). Using thematic analysis in psychology. Qualitative Research in Psychology, 3(2), 77-101. doi: http://dx.doi.org/10.1191/1478088706qp063oa

Bullough, R. V. Jr. (2012). Mentoring and new teacher induction in the United States: A review and analysis of current practices. Mentoring \& Tutoring: Partnership in Learning, 20(1), 57-74. doi: http://dx.doi.org/10.1080/13611267.2012.645600

Chang, M.-L. (2009). An appraisal perspective of teacher burnout: Examining the emotional work of teachers. Educational Psychology Review, 21(3), 193-218. doi: http://dx.doi.org/10.1007/s10648-009-9106-y

Clark, S. K., \& Byrnes, D. (2012). Through the eyes of the novice teacher: Perceptions of mentoring support. Teacher Development, 16(1), 43-54.

doi: http://dx.doi.org/10.1080/13664530.2012.666935 
Darling-Hammond, L. (1997). Doing what matters most: Investing in quality teaching. New York: The National Comission on Teaching \& America's Future.

Darling-Hammond, L. (2003). Access to quality teaching: An analysis of inequality in California's public schools. Santa Clara Law Review, 43, 101-239.

Davis, S., Darling-Hammond, L., LaPointe, M., \& Meyerson, D. (2005). School leadership study: Developing successful principals. Stanford: Stanford Educational Leadership Institute.

Day, C., \& Gu, Q. (2009). Veteran teachers: Commitment, resilience and quality retention. Teachers and Teaching, 15(4), 441-457. doi: http://dx.doi.org/10.1080/13540600903057211

Devos, C., Dupriez, V., \& Paquay, L. (2012). Does the social working environment predict beginning teachers' self-efficacy and feelings of depression? Teaching and Teacher Education, 28(2), 206-217. doi: http://dx.doi.org/10.1016/j.tate.2011.09.008

Dinham, S., \& Scott, C. (1996). The teacher 2000 project: A study of teacher satisfaction, motivation and health. Sydney: University of Western Sydney, Nepean.

Dinham, S., \& Scott, C. (2000). Moving into the third, outer domain of teacher satisfaction. Journal of Educational Administration, 38(4), 379-396. doi: http://dx.doi.org/10.1108/09578230010373633

Eisenschmidt, E. (2006). Kutseaasta kui algaja õpetaja toetusprogrammi rakendamine Eestis (doktoritöö). Tallinn: Tallinna Ülikool. Külastatud aadressil http://e-ait.tlulib.ee/103/7/eisenschmidt_eve.pdf.

Eisner, E. W. (1991). The enlightened eye: Qualitative inquiry and the enhancement of educational practice. New York: Macmillan.

Feiman-Nemser, S., Carver, C., Schwille, S., \& Yusko, B. (1999). Beyond support: Taking new teachers seriously as learners. In M. Scherer (Ed.), A better beginning: Supporting and mentoring new teachers (pp. 3-12). Alexandria: Association for Supervision and Curriculum Development.

Franke, A., \& Dahlgren, L. O. (1996). Conceptions of mentoring: An empirical study of conceptions of mentoring during the school-based teacher education. Teaching and Teacher Education, 12(6), 627-641. doi: http://dx.doi.org/10.1016/S0742-051X(96)00004-2

Ginns, I. S., Heirdsfield, A. M., Atweh, B., \& Watters, J. J. (2001). Beginning teachers becoming professionals through action research. Educational Action Research, 9(1), 111-133. doi: http://dx.doi.org/10.1080/09650790100200140

Halford, J. M. (1998). Easing the way for new teachers. Educational Leadership, 55(5), $3-36$.

Harrison, J. K., Lawson, T., \& Wortley, A. (2005). Mentoring the beginning teacher: Developing professional autonomy through critical reflection on practice. Reflective Practice, 6(3), 419-441. doi: http://dx.doi.org/10.1080/14623940500220277

Hobson, A. J., Ashby, P., Malderez, A., \& Tomlinson, P. D. (2009). Mentoring beginning teachers: What we know and what we don't? Teaching and Teacher Education, 25(1), 207-216. doi: http://dx.doi.org/10.1016/j.tate.2008.09.001

Holloway, J. H. (2001). The benefits of mentoring. Educational Leadership, 58(8), 85-86. Hope, W. C. (1999). Principals' orientation and induction activities as factors in teacher retention. The Clearing House, 73(1), 54-56.

doi: http://dx.doi.org/10.1080/00098659909599641 
Howe, E. R. (2006). Exemplary teacher induction: An international review. Educational Philosophy and Theory, 38(3), 287-297.

doi: http://dx.doi.org/10.1111/j.1469-5812.2006.00195.x

Høigaard, R., Giske, R., \& Sundsli, K. (2012). Newly qualified teachers' work engagement and teacher efficacy influences on job satisfaction, burnout, and the intention to quit. European Journal of Teacher Education, 35(3), 347-257.

doi: http://dx.doi.org/10.1080/02619768.2011.633993

Ingersoll, R., \& Kralik, J. M. (2004). The impact of mentoring on teacher retention: What the research says. Graduate School of Education GSE Publications. Pennsylvania: University of Pennsylvania.

Ingersoll, R., \& Smith, T. (2003). The wrong solution to the teacher shortage. Educational Leadership, 60(8), 30-33.

Johnson, S. M. (2006). The workplace matters: Teacher quality, retention, and effectiveness Washington: National Educational Association.

Johnson, S. M., Berg, J. H., \& Donaldson, M. L. (2005). Who stays in teaching and why: $A$ review of the literature on teacher retention. Washington: NRTA.

Kealy, M. V. (2010). A leadership focus on teacher effectiveness: Support for novice teachers. Journal of Special Educational Leadership, 23(1), 52-54.

Kouzes, J. M., \& Posner, B. Z. (2011). Credibility: How leaders gain and lose it, why people demand it. San Francisco: Jossey-Bass. doi: http://dx.doi.org/10.1002/9781118983867

Kutseaastat läbiva õpetaja tugiprogramm (2010). Külastatud aadressil https://www.is.ut.ee/pls/ois_sso/!tere.tulemast.

Ladd, H. F. (2011). Teachers' perceptions of their working conditions: How predictive of planned and actual teacher movement? Educational Evaluation and Policy Analysis, 33(2), 235-261. doi: http://dx.doi.org/10.3102/0162373711398128

Lam, B., \& Yan, H. (2011). Beginning teachers' job satisfaction: The impact of schoolbased factors. Teacher Development, 15(3), 333-348. doi: http://dx.doi.org/10.1080/13664530.2011.608516

Lawson, H. A. (1992). Beyond the new conception of teacher induction. Journal of Teacher Education, 43(3), 163-172. doi: http://dx.doi.org/10.1177/0022487192043003002

Leijen, Ä., Kullasepp, K., \& Ots, A. (2013). Õpetaja professionaalse rolli internaliseerimise hindamine õpetajakoolituse esmaõppe üliõpilaste hulgas. Eesti Haridusteaduste Ajakiri, 1, 72-96. doi: http://dx.doi.org/10.12697/eha.2013.1.05

Leithwood, K., Seashore Louis, K., Anderson, S., \& Wahlstrom, K. (2004). How leadership influences student learning. The Wallace Foundation. Retrieved from http://www.wallacefoundation.org/knowledge-center/school-leadership/keyresearch/Documents/How-Leadership-Influences-Student-Learning.pdf.

Leonard, L., \& Leonard, P. (2003). The continuing trouble with collaboration: Teachers talk. Current Issues in Education, 6(15).

Retrieved from http://cie.ed.asu.edu/volume6/number15/.

Leslie, K., Lingard, L., \& Whyte, S. (2005). Junior faculty experiences with informal mentoring. Medical Teacher, 27(8), 693-698. doi: http://dx.doi.org/10.1080/01421590500271217

Löfström, E., \& Eisenschmidt, E. (2009). Novice teachers' perspectives on mentoring: The case of the Estonian induction year. Teaching and Teacher Education, 25(5), 681-689. doi: http://dx.doi.org/10.1016/j.tate.2008.12.005 
Marable, M. A., \& Raimondi, S. L. (2007). Teachers' perceptions of what was most (and least) supportive during their first year of teaching. Mentoring \& Tutoring, 15(1), 25-37. doi: http://dx.doi.org/10.1080/13611260601037355

McKerrow, K. (1996). Support then solutions: The supervision of teachers. The Clearing House: A Journal of Educational Strategies, Issues and Ideas, 69(6), 330-332.

Mullen, C. A. (2005). The mentorship primer. New York: Peter Lang.

Nias, J. (2005). Why teachers need their colleagues: A developmental perspective. In D. Hopkins (Ed.), The practice and theory of school improvement (pp. 223-237). Dordrecht: Springer. doi: http://dx.doi.org/10.1007/1-4020-4452-6_12

Poom-Valickis, K., \& Löfström, E. (2014). Pikiuuring õpetajaks õppijate professionaalse identiteedi kujunemisest. Eesti Haridusteaduste Ajakiri, 2(1), 241-271. doi: http://dx.doi.org/10.12697/eha.2014.2.1.10

Rainbird, H., Fuller, A., \& Munro, A. (Eds.) (2004). Workplace learning in context. London, New York: Routledge.

Smith, T. M., \& Ingersoll, R. M. (2004). What are the effects of induction and mentoring on beginning teacher turnover? American Educational Research Journal, 41(3), 681-714. doi: http://dx.doi.org/10.3102/00028312041003681

Smith, K., \& Maclay, M. (2007). Curates' eggs? Secondary trainee teachers' experience of the Graduate Teacher Programme and the Postgraduate Certificate in Education. Journal of Education for Teaching, 33(1), 35-54.

doi: http://dx.doi.org/10.1080/02607470601098294

Stokking, K. M., Leenders, F. J., De Jong, J., \& Van Tartwijk, J. (2003). From student to teacher: Reducing practice shock and early dropout in the teaching profession. European Journal of Teacher Education, 26(3), 329-350. doi: http://dx.doi.org/10.1080/0261976032000128175

Tillman, L. C. (2003). Mentoring, reflection, and reciprocal journaling. Theory Into Practice, 42(3), 226-233. doi: http://dx.doi.org/10.1207/s15430421tip4203_9

Tynjälä, P. (2013). Toward a 3-P model of workplace learning: A literature review. Vocations and Learning, 6(1), 11-36. doi: http://dx.doi.org/10.1007/s12186-012-9091-z

Tynjälä, P., \& Heikkinen, L. T. H. (2011). Beginning teachers' transition from pre-service education to working life. Zeitschrift für Erziehungswissenschaft, 14(1), 11-33. doi: http://dx.doi.org/10.1007/s11618-011-0175-6

Ulvik, M., \& Langørgen, K. (2012). What can experienced teachers learn from newcomers? Newly qualified teachers as a resource in schools. Teachers and Teaching, 18(1), 43-57. doi: http://dx.doi.org/10.1080/13540602.2011.622553

Vonk, J. H. C. (1995). Conceptualizing novice teachers' professional development: A base for supervisory interventions. San Francisco: American Education Research Association.

Walsdorf, K. L., \& Lynn, S. K. (2002). The early years: Mediating the organizational environment. The Clearing House, 75(4), 190-194. doi: http://dx.doi.org/10.1080/00098650209604929

Wenger, E. (1998). Communities of practice: Learning, meaning, and identity. New York: Cambridge University Press. doi: http://dx.doi.org/10.1017/CBO9780511803932

Worthy, J. (2005). 'It didn't have to be so hard': The first years of teaching in an urban school. International Journal of Qualitative Studies in Education, 18(3), 379-398. doi: http://dx.doi.org/10.1080/09518390500082699 


\title{
Novice teachers' workplace experiences of collegiate support
}

\author{
Marvi Remmik ${ }^{\mathrm{a}}$, Liina Lepp ${ }^{\mathrm{a}}$, Ingrid Koni ${ }^{\mathrm{a}}$ \\ ${ }^{a}$ University of Tartu, Institute of Educational Sciences
}

\section{Summary}

\section{Introduction}

Being a teacher requires professionalism and, in case of an inexperienced teacher, a lot of effort. Research has shown that the first years of practice are of crucial importance with regard to the professional development of the novice teacher as the initial school and teaching experiences either encourage or discourage any ambition to have a career as a teacher (Ginns et al., 2001).

To support novice teachers, induction year programmes with varying support activities have been developed and launched in many countries, including Estonia. Several previous studies show that induction activities support novice teachers' adaptation in their first years of teaching (e.g. Ingersoll \& Kralik, 2004). On the other hand, researchers have questioned the effectiveness of support systems designed for novice teachers in schools with unsupported professional cultures, and have revealed that few schools are prepared to offer novice teachers a comprehensive array of induction support (Birkeland \& Feiman-Nemser, 2012). Therefore, it has been found that the topic of induction activities and support for novice teachers requires further research and that the need to understand the novice teachers' viewpoint of an institution as one of the support means for a novice teachers' survival (e.g. Bullough, 2012).

Research has shown that the quality of school leadership is the dominant factor when evaluating the working conditions (Ladd, 2011) and that a fair and democratic leadership, good school management, and proper recognition of efforts contribute significantly to teachers' feelings of satisfaction (Lam \& Yan, 2011). School principals are described in research literature, as the key sources of support and guidance playing an important role in relieving novice teachers' feelings of isolation and loneliness and provide positive reinforcement, without which novices may feel frustrated and abandoned (McKerrow, 1996). Therefore, supportive school principals

1 Institute of Educational Sciences, Faculty of Social Sciences and Education, University of Tartu, Salme 1a, 50103 Tartu, Estonia; marvi.remmik@ut.ee 
should persistently foster work relationships and remove barriers by providing resources necessary for implementation, in other words to, enable others to act (Clark \& Byrnes, 2012).

The aim of this qualitative study is to analyse novice teachers' descriptions of adaptation to the social working environment and the presence, or lack, of support from the members of the institution. The following research questions were formulated:

1. How do novice teachers describe their adaptation to the school community?

2. What kinds of support are provided to novice teachers by colleagues?

3. What kind of support would novice teachers like to receive from their colleagues?

\section{Methodology}

The sample consisted of 13 novice teachers working at different comprehensive schools, all of whom attended the induction year's seminars.

The data was collected in the induction year seminars during one academic year, using audio recordings of the full sets of the seminars. During the audio recorded seminars the novice teachers could, and did, talk freely about external issues in addition to general induction year compulsory module issues.

Audio recordings were fully transcribed and analysed using qualitative thematic data analysis techniques. We followed the analysis guidelines of the phases described by Braun and Clarke (2006). To increase the credibility of the findings, two authors undertook parallel identification of themes and sub-themes. In line with the research questions, we generated an initial list of ideas about what was in the data. As a second phase, the coding of interesting features of the data in a systematic fashion across the entire data set was carried out. Subsequently, the emerged codes were organised under themes and sub-themes. For example, codes "positive mentoring relationship”, „neutral mentoring relationship”, „negatively perceived mentoring relationship” formed a sub-theme „Functioning mentoring relationship”. The latter sub-theme was organised with the sub-theme „Expectations for a mentor" under a theme „Mentoring and collegial support”. After that, the themes were reviewed in collaboration with researchers - to check if the themes worked in relation to the coded extracts and the complete dataset. In the final phase of data analysis, we used the summary table that was a result of coding and categorising, to write a summary of sub-themes and themes using QCAmap software. 
Four thematic categories emerged from the data analysis: collegiate expectations, the principal as the supporter of novice teachers, formal mentoring and collegial support, and shared understandings.

\section{Major results and discussion}

Previous studies (e.g. Ladd, 2011; Leithwood, et al., 2004) indicate that the predominant factor among the working conditions is the quality of school leadership. Thus, the principal has a crucial role in developing people as well as offering intellectual support and stimulation to enable them to improve their work. The results of this particular study partly verify this claim as the novice teachers of the Induction Year's seminars were also aware of, and emphasised the importance of, the principal. The novice teachers perceived the principal as a supporter mainly in the early stage of their work and described the principal's activities through their own personal contacts with the principal. Apart from that, the novice teachers did not discuss what the role of a principal is in shaping the school culture, and if or indeed, in which areas the novice teacher has matching values with the principal. On the other hand, the novice teachers in their reflections did not express an expectation of the principal to communicate with them in any way, to solve the differences of opinion related directly to mentoring or support their professional development in any way.

This could be explained by the fact that in their first year, novice teachers might not comprehend the mechanisms of a school as an institution and the roles of all of the community members. Therefore, as novice teachers do not see all of the roles of a principal and do not learn about them due to the scarcity of communication, they are also unable to describe it in their reflections. Thus we see that on behalf of supporting a novice teacher as effectively as possible, more regular and frequent contact between the novice teacher and the principal would be required, despite the fact that the former might not perceive it as useful. Even in the recruiting and early adaptation phases, the principals should make an appointment with the novice teachers to discuss expectations, possibilities and known needs for support on both sides. Through the creation of a confidential atmosphere and an understanding of both sides' expectations and needs, as well as levelling the understandings of the values of the school as an institution, future co-operation of all sides may be assumed to be more fruitful.

Alternatively, it is important to consider the principals' own awareness about the kinds of support novice teachers need and how it is offered. Are the principals' knowledgeable about the basic principles of mentoring in 
general, and on which to base the choice of a suitable mentor for a teacher? Although the framework of the Estonian induction year system does train mentors, the training of principals has yet to be included. As inclusion would benefit the system as a whole, the training of principals does need more attention and research.

The results of this particular study are thought-provoking as, according to current Estonian regulations, mentors assigned to novice teachers by principals must have passed mentor training (or have extensive teaching experience) and should, thus be aware of the general principles of mentoring as well as of applying them. Nevertheless, not all of the novice teachers received this level of support. Indeed the novice teachers referred to mentors who are not knowledgeable about the main principles of mentoring and do not co-operate sufficiently with novice teachers. Consequently, the co-operation between novice teacher and mentor is hindered and the base for shared understandings about learning and teaching aggravated. Cooperation plays a crucial role in supporting novice teachers. However, cooperation infers taking other people into consideration, keeping an open mind and an attitude that values the opinions of all the members of institution. Hence the novice teachers had strong feelings about shared understandings and collegial support in order to adapt to their new workplaces and co-operation as a process. Collegiate expectations play a no less significant role in those processes. The novice teacher should be provided with suitable conditions for communicating with their colleagues and also for sharing their own experiences. Through these activities, the novice teacher gains greater awareness of self, is supported in their professional development and supports the development of the school as an institution.

Keywords: novice teachers, induction year, colleagues, school principal, adaptation 